\title{
PENGARUH JUMLAH PENDUDUK USIA PRODUKTIF, KEMISKINAN DAN INFLASI TERHADAP PERTUMBUHAN EKONOMI DI KABUPATEN BIREUEN
}

\author{
Khairil Anwar ${ }^{* a}$, Fatmawati ${ }^{* b}$ \\ * Fakultas Ekonomi dan Bisnis Universitas Malikussaleh \\ a Corresponding author: khairil.anwar.semsi@gmail.com \\ b fatmawati@gmail.com
}

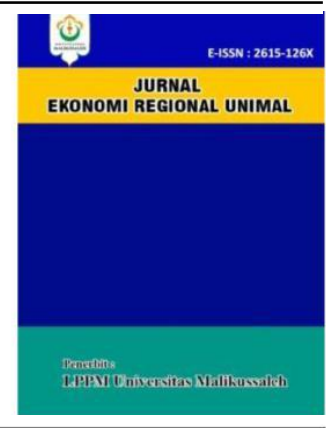

A R T I CLE INFORMATION

A B S T R A C T

Keywords:

Number of Productive age

Population, Poverty, Inflation.
The purpose of this study is to determine the effect of the number of productive age population, poverty and inflation on economic growth in Bireuen District Aceh Indonesia. The data used in this study are secondary data in the form of time series during 2006-2016 and data analysis using multiple linear regression analysis model. The results of the study here found that the number of productive age population had a significant effect, while poverty and inflation had no effect on economic growth in Bireuen District in the period 2006-2016.

\section{PENDAHULUAN}

Perkembangan perekonomian merupakan gejala yang timbul dari beberapa jenis sektor yang secara tidak langsung menjelaskan tingkat pertumbuhan kemajuan suatu negara. Bukan juga negar-negara tetapi juga bagi suatu daerah, indikator pertumbuhan ekonmi ini begitu penting untuk melihat kesuksesan kegiatan perekonomian suatu daerah di masa mendatang. Hal ini diakui sebagai sebuah proses dari perubahan yang berlangsung secara sadar dan terencana serta berkelanjutan dengan sasaran pertamanya yaitu untuk menaikkan kesejahteraan kehidupan manusia ataupun masyarakat.

Perkembangan pembangunan harus dilakukan dan berjalan sesuai dengan kebijakan publik yang telah disusun sebelumnya. Kebijakan publik yang disusun harus mencakup kepentingan dari seluruh masyarakat (Miraza, 2005). Di sisi lain pembangunan yang berkesinambungan harus dapat memberi tekanan pada mekanisme ekonomi, sosial, politik dan kelembagaan, baik dari sektor swasta maupun non swasta, guna menciptakan kualitas hidup yang lebih layak (Mahalli, 2005).

Pembangunan di Provinsi Aceh yang berlangsung secara keseluruhan dan berkesinambungan telah meningkatkan perekonomian masyarakat. Pencapaian beberapa hasil pembangunan yang sangat dirasakan oleh para masyarakat dan ini tidak terlepas dari usaha keras bersama-sama antara pemerintah maupun para masyarakat. Namun di sisi lainnya ada beberapa masalah untuk memaksimalkan potensi sumber daya manusia maupun sumber modal masih dihadapi oleh para penentu kebijakan di tingkat daerah. Pertumbuhan ekonomi disebabkan oleh beberapa hal seperti pertumbuhan penduduk usia produktif, kemiskinan dan inflasi.

Provinsi Aceh pada tahun 2016 dengan pendudukan sebanyak 4.597.308 dengan jumlah laki-laki 2.300.442 orang, sedangkan sisanya perempuan berjumlah 2.296 .866 orang terdapat sebanyak 338.300 orang diantaranya adalah penduduk usia kerja yang masih dalam kategori pengangguran. Demikian juga di Kabupaten Bireuen yang merupakan salah satu wilayah yang penduduknya mengalami perkembangan hal ini berdasarkan proyeksi luas wilayah sekitar $1.901,21 \mathrm{~km} 2$, yang dihuni oleh 435.300 jiwa penduduk.

Kabupaten Bireuen memiliki tingkat kemiskinanan yang tinggi. Menurut pengamatan penulis penyebab utama tingginya tingkat 
kemiskinan di Kabupaten Bireuen adalah terbatasnya lapangan pekerjaan, sementara jumlah penduduk selalu meningkat setiap tahunnya. Disamping itu, karakteriktik penduduk Kabupaten Bireuen yang manyoritas kurang produktif dalam memanfaatkan potensi yang ada. Hal ini dikarenakan turunnya kualitas SDM, sehingga susah untuk keluar dari kemiskinan tersebut.

Di samping kemiskinan, pertumbuhan ekonomi juga ikut dipengaruhi oleh inflasi. Inflasi merupakan indikator yang berpengaruh terhadap tingkat kemiskinan. Inflasi bisa menimbulkan beberapa penyebab buruk kepada individu dan para masyarakat serta aktifitas perekonomian secara keseluruhan. Oleh sebab itu upah riil para pekerja akan merosot disebabkan oleh inflasi dan keadaan ini berarti tingkat kemakmuran segolongan besar masyarakat mengalami kemerosotan (Sukirno, 2002).

Berdasarkan data di atas bisa dilihat fenomena yang terjadi di Kabupaten Bireuen, dimana seiring meningkatnya angka kelahiran, maka akan meningkatkan jumlah penduduk terutama usia produktif, namun kesempatan kerja yang dimiliki Bireuen masih sangat terbatas, hal ini berdampak pada lambannya laju pertumbuhan ekonomi. Pertumbuhan ekonomi yang ditargetkan setiap tahun pun tidak pernah tercapai. Permasalahan lainnya, usia produktif banyak yang tidak memiliki keterampilan hingga mereka banyak terserap pada sektor usaha sebagai buruh.

Di samping pertumbuhan penduduk, kemiskinan di Kabupaten Bireuen menyebabkan banyak sektor tidak berkontribusi terhadap PDRB. Semakin tingginya jumlah penduduk miskin, maka unit usaha masyarakat menjadi tidak berkembang karena masyarakat tidak memiliki modal untuk memproduksi barang maupun jasa.

Demikian juga dengan inflasi, nilai inflasi yang tinggi di Kabupaten Bireuen menjadikan hampir sebagian besar pengeluaran masyarakat untuk kebutuhan konsumtif, sedangkan untuk hal yang produktif senantiasa kekurangan modal.

Fenomena ini menarik untuk diteliti, hal ini disebabkan dengan meningkatnya pertumbuhan jumlah penduduk termasuk di dalamnya penduduk usia produktif, pemerintah Kabupaten Bireuen tidak mampu menyediakan lapangan kerja, hal ini dikhawatirkan akan terjadi peningkatan angka pengangguran setiap tahunnya yang menjadi penyebab kemiskinan terbesar. Tingginya jumlah kemiskinan menyebabkan produktivitas menurun dan tingginya harga barang menyebabkan daya beli masyarakat menurun. Hal yang menarik lainnya, dengan adanya sumber daya melimpah khususnya potensi pertanian, namun tidak mampu mengelola sumber daya yang tersedia.

Berdasarkan permasalahan di atas, penulis hendak melakukan penelitian yang berjudul "Pengaruh Jumlah Penduduk Usia Produktif, Kemiskinan dan Inflasi Terhadap Pertumbuhan Ekonomi di Kabupaten Bireuen”.

\section{TINJAUAN PUSTAKA}

\subsection{Definisi Penduduk}

Penduduk merupakan elemen primer dalam meningkatkan produksi dan. Mereka memegang peranan yang begitu penting karena menciptakan tenaga kerja dan tenaga ahli serta pimpinan perusahaan dan juga tenaga usahawan yang dibutuhkan untuk melakukan aktifitas ekonomi.

Pertumbuhan penduduk ialah keseimbangan yang dinamis antara kekuatan-kekuatan yang menambah dan kekuatan-kekuatan yang menurunkan jumlah penduduk. Apabila angka fertilitas lebih besar dari pada angka mortalitas, maka pertumbuhan penduduk menjadi positif. Begitu juga dengan migrasi, apabila nilai migrasi masuk lebih besar daripada nilai migrasi keluar maka pertumbuhan penduduk menjadi positif (Subri, 2003).

\subsection{Definisi Penduduk Usia Produktif}

Penduduk usia produktif adalah usia yang menghasilkan barang dan jasa. BPS mengambil umur 10 tahun ke atas sebagai usia kerja. Akan tetapi mulai dari tahun 1998 mulai memakai usia 15 tahun ataupun lebih tua dari batas usia kerja pada tahun sebelumnya (Subri, 2003).

\subsection{Kemiskinan}

Kemiskinan adalah keadaan ketidakmampuan masyarakat memenuhi kebutuhan primer. Hal ini bisa dilihat dengan turunnya sumber-sumber pemasukan sehingga dapat digunakan untuk membeli keperluan pokok seperti pangan dan sandang serta papan. Pada prinsipnya, kelayakan suatu masyarakat tidak hanya mencukupi kebutuhan pangan, tapi juga 
kesehatan dan pendidikan. Berdasarkan pendapat ini, masyarakat dikatakan miskin apabila mempunyai penghasilan rendah dari rata-rata penghasilan sehingga tidak banyak mempunyai peluang untuk bisa mensejahterakan diri mereka (Suryawati, 2004).

\section{$2.4 \quad$ Inflasi}

Sesuai dengan pernyataan dari (Latumaerissa, 2011) definsi singkat dari inflasi ialah kecenderungan dari harga-harga untuk naik secara terus menerus. Selain terjadi secara berkelanjutan. Peningkatan harga dapat dikatakan sebagai inflasi jika peningkatan harga tersebut mencakup semua jenis macam barang. Sesuai dengan pernyataan dari (Mankiw, Quah and Peter, 2012) inflasi ialah kenaikan tingkat harga secara keseluruhan.

\subsection{Pertumbuhan Ekonomi}

Menurut Kuznets dalam (Todaro, 2006), pertumbuhan ekonomi adalah kenaikan jangka panjang dalam kemampuan suatu Negara untuk menyediakan semakin banyak jenis barang-barang ekonomi kepada penduduknya. Kemampuan ini tumbuh sesuai dengan kemajuan teknologi, dan penyesuaian kelembagaan dan idiologis yang diperlukannya.

\subsection{Pengaruh Jumlah Penduduk Usia Produktif Terhadap Pertumbuhan Ekonomi}

Pertumbuhan penduduk (yang juga diakibatkan pertumbuhan penduduk umur produktif walaupun dengan tenggang waktu) secara tradisional dianggap merupakan faktor positif dalam mendorong pertumbuhan ekonomi. Jelaslah bahwa hal ini akan tergantung pada kemampuan sistem ekonomi untuk menyerap dan mempekerjakan secara produktif tenaga kerja tambahan itu, suatu kemampuan yang sangat erat hubungannya dengan tingkat dan jenis akumulasi modal dan tersedianya faktor-faktor lain yang terkait seperti keterampilan manajerial dan administrasi (Todaro, 2006). Karena jumlah penduduk meningkat setiap periode yang dengan sendiri nya keperluan konsumsi sehari-hari juga akan meningkat setiap periodenya, maka diperlukan penambahan pengahsilan setiap periodenya (Tambunan, 2003).

\subsection{Pengaruh Kemiskinan Terhadap}

\section{Pertumbuhan Ekonomi}

Menurut Kuznet (Tambunan, 2003), pertumbuhan dan kemiskinan memiliki korelasi yang sangat kuat, karena pada tahap awalny sebuah proses pembangunan tingkat kemiskinan cenderung naik dan pada saat mendekati tahap akhir pembangunan jumlah orang miskin perlahan-lahan akan berkurang.

\subsection{Pengaruh Inflasi $\quad$ Terhadap Pertumbuhan Ekonomi}

Inflasi memberikan dampak buruk pada pertumbuhan ekonomi. Menurut Murni (2006) inflasi yang tinggi tingkatannya tidak akan menggalakkan perkembangan ekonomi suatu negara. Ketika inflasi naik maka akan menyebabkan pertumbuhan ekonomi menurun.

\section{METODE PENELITIAN}

Objek penelitiannya adalah jumlah penduduk usia produktif, kemiskinan, inflasi dan pertumbuhan ekonomi Kabupaten Bireuen. Data dalam penelitian ini adalah data BPS Kabupaten Bireuen Provinsi Aceh sejak tahun 2006-2016.

\section{Definisi Operasionalisasi Variabel}

Definisi operasional variabel dalam penelitian ini adalah sebagai berikut:

1. Pertumbuhan ekonomi ( $\mathrm{Y}$ )

Kenaikan kapasitas produksi barang dan jasa secara fisik dalam kurun waktu tertentu. diukur dalam persentase (rasio).

2. Penduduk Usia Produktif (X1)

Segolongan penduduk yang berumur 15-64 t di Kabupaten Bireuen, diukur dalam satuan jiwa.

3. Kemiskinan (X)

Jumlah penduduk yang miskin di Kabupaten Bireuen, diukur dalam satuan Kepala Keluarga (KK).

4. Inflasi (X)

Tingkat peningkatan harga barang di Kabupaten Bireuen, diukur dalam persentase (rasio).

\section{Metode Analisis Data}

Data yang didapatkan dari sumber data, kemudian di tabulasi dan diolah dengan 
menggunakan rumus persentase yang berguna untuk melihat kecenderungan-kecenderungan indikator dari masing-masing indikator. Selanjutnya untuk mengukur besaran dampak dari variabel-variabel, maka data dianalisis dengan menggunakan persamaan regresi linier berganda (Sugiyono, 2009)

$$
\begin{array}{ll} 
& \mathrm{Y}=\mathrm{a}+\mathrm{bX} 1+\mathrm{bX}_{2}+\mathrm{bX}_{3+\mathrm{e}} \\
\mathrm{Y} & =\text { Pertumbuhan ekonomi (persen) } \\
\mathrm{X}_{1} & =\text { Penduduk Usia Produktif (jiwa) } \\
\mathrm{X}_{2} & =\text { Kemiskinan }(\mathrm{KK}) \\
\mathrm{X}_{3} & =\text { Inflasi (persen) } \\
\mathrm{a} & =\text { Konstanta } \\
\mathrm{b} & =\text { Koefesien yang dicari } \\
\mathrm{e} & =\text { standar error }
\end{array}
$$

\section{HASIL PENELITIAN DAN PEMBAHASAN}

\subsection{Hasil Penelitian}

\subsubsection{Jumlah Penduduk Usia Produktif}

Penduduk usia produktif merupakan golongan penduduk umur 15-64 tahun di Kabupaten Bireuen, diukur dalam satuan jiwa. Secara ringkas jumlah penduduk usia produktif di Kabupaten Bireuen tahun 2006-2016 bisa dilihat pada Gambar 1 berikut:

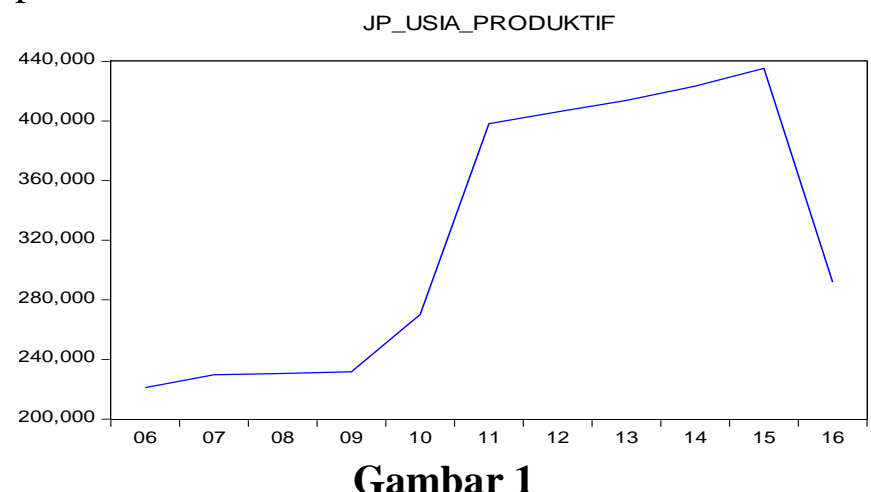

\section{Jumlah Penduduk Usia Produktif di Kabupaten Bireuen 2006-2016}

Berdasarkan Gambar 1 di atas dapat dilihat bahwa perkembangan jumlah penduduk usia produktif di Kabupaten Bireuen mengalami peningkatan sejak 2006-2016. Peningkatan terbesar terjadi pada tahun 2016 sedangkan terendah tahun 2006.

\subsubsection{Kemiskinan}

Jumlah penduduk miskin di Kabupaten Bireuen, diukur dalam satuan Kepala Keluarga (KK). Secara ringkas jumlah penduduk miskin di
Kabupaten Bireuen tahun 2006-2016 bisa dilihat pada Gambar 2 berikut:

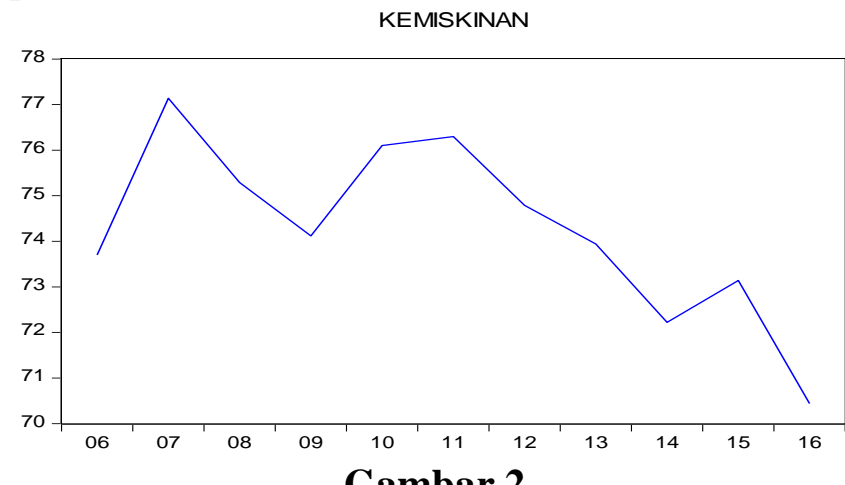

\section{Jumlah Penduduk Miskin di Kabupaten} Bireuen 2006-2016

Berdasarkan Gambar 4.2 di atas bisa dilihat bahwa perkembangan jumlah penduduk miskin di Kabupaten Bireuen mengalami peningkatan pada tahun 2007 dan 2011, sedangkan terendah pada tahun 2016.

\subsubsection{Inflasi}

Inflasi merupakan tingkat peningkatan harga barang maupun jasa yang diukur dalam satu persen. Secara ringkas kondisi inflasi di Kabupaten Bireuen tahun 2006-2016 bisa dilihat pada Gambar 3 berikut:

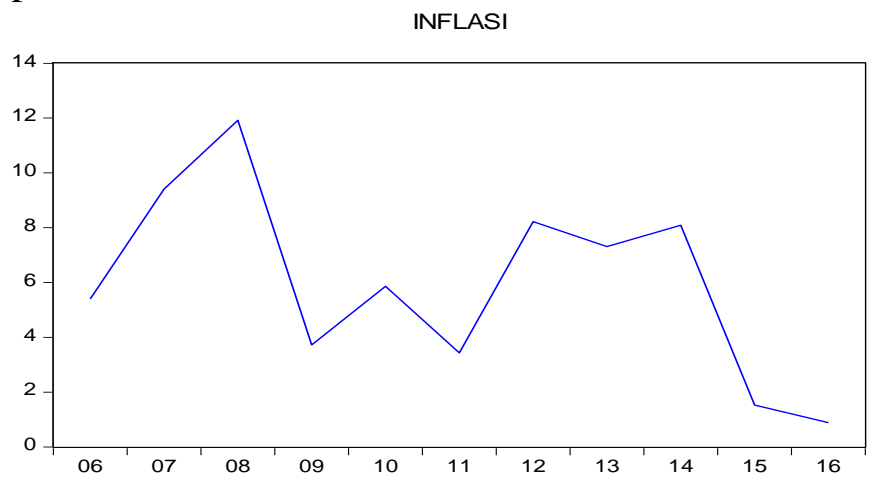

Gambar 3

Inflasi di Kabupaten Bireuen 2006-2016

Berdasarkan Gambar 3 di atas bisa dilihat bahwa perkembangan inflasi di di Kabupaten Bireuen mengalami peningkatan tertinggi pada tahun 2008, 2012 dan 2014, sedangkan terendah pada tahun 2009 dan 2015.

\subsubsection{Pertumbuhan Ekonomi}

Penduduk usia produktif merupakan segolongan penduduk yang berumur 15-64 tahun di Kabupaten Bireuen, diukur dalam satuan jiwa. Secara ringkas jumlah penduduk usia produktif di 
Kabupaten Bireuen tahun 2006-2016 bisa dilihat pada Gambar 4 berikut:

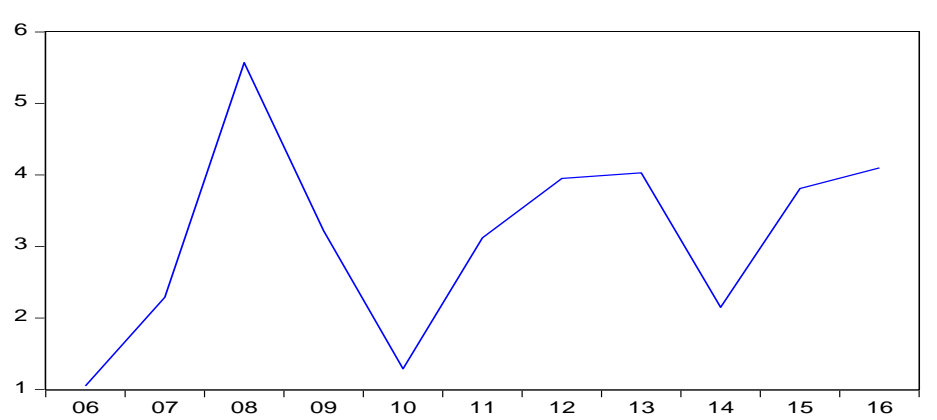

Gambar 4

\section{Pertumbuhan Ekonomi di Kabupaten Bireuen 2006-2016}

Berdasarkan Gambar 4 di atas bisa dilihat bahwa pertumbuhan ekonomi di Kabupaten Bireuen mengalami peningkatan tertinggi pada tahun 2008, sedangkan terendah pada tahun 2010 dan 2014.

\subsection{Uji Normalitas}

Penelitian ini menggunakan metode JarqueBera (J-B) Test untuk melihat normal ataupun tidak normalnya model regresi, variabel peganggu atau residual. Dengan cara membandingkan nilai J$\mathrm{B}$ hitung dengan nilai $\mathrm{X}^{2}$ (Chi-Square) tabel. Apabila nilai J-B hitung > nilai abel, maka nilai residual terdistribusi dengan tidak normal dan apabila nilai J-B hitung < nilai tabel, maka nilai residual terdistribusi dengan normal.

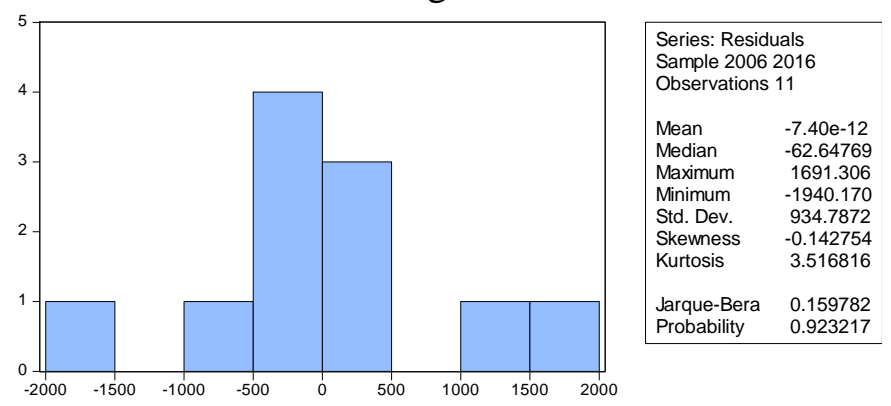

\section{Gambar 5}

Uji Normalitas

Sumber : Data eviews (data diolah)

Untuk melihat normal ataupun tidak normalnya model regresi, variabel peganggu atau residual. Dengan cara membandingkan nilai J-B hitung dengan nilai $\mathrm{X}^{2}$ (Chi-Square) tabel. Nilai tabel dengan $\mathrm{df}=11-4=7=14.067$. Jika dibandingkan dengan nilai Jarque-Bera pada gambar di atas sebesar 0.159, maka bisa ditarik kesimpulan jika model regresi, variabel peganggu atau residual terdistribusi normal karena nilai Jarque-Bera $>$ nilai tabel atau $0.159<14.067$ dengan signifikansi >0.05 yakni 0.923 .

\subsection{Analisis Regresi Linier Berganda}

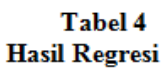

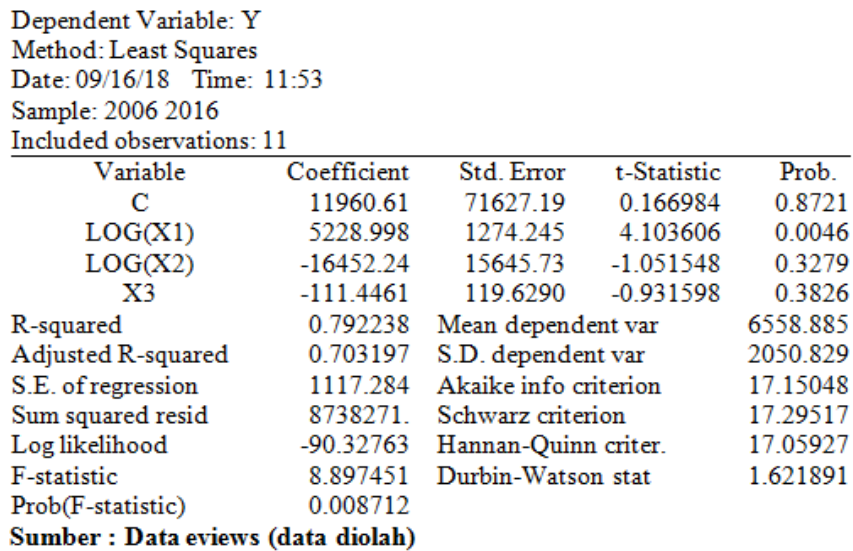

Berdasarkan data dari tabel 4 diatas dapat dibuat persamaan regresi linear berganda sebagai berikut:

$Y=11960.61+5228.998 \log X_{1-16452.24} \log X_{2^{-}}$ $111.4461 \mathrm{X}_{3}$

Dari formulasi model di atas menunjukkan bahwa nilai variabel konstanta sebesar 11960.61 yang berarti bahwa jika jumlah usia produktif, kemiskinan dan inflasi nilainya 0 , maka pertumbuhan ekonomi Bireuen meningkat sebesar $1.19 \%$.

Nilai koefisien variabel jumlah usia produktif adalah sebesar 5228.998 (bernilai positif), yang berarti apabila jumlah usia produktif bertambah 1\%, maka akan meningkatkan pertumbuhan ekonomi sebesar 5,22\%.

Nilai koefesien variabel kemiskinan adalah sebesar -16452.24 (bernilai negatif) yang berarti apabila kemiskinan meningkat $1 \%$, maka akan menurunkan pertumbuhan ekonomi sebesar $1,64 \%$.

Nilai koefesien variabel inflasi adalah sebesar -111.4461 (bernilai negatif) yang berarti apabila inflasi meningkat $1 \%$, maka akan menurunkan pertumbuhan ekonomi sebesar $1,11 \%$.

\subsection{Uji Asumsi Klasik}

\subsubsection{Uji Hetroskedastisitas}

Suatu penelitian dikatakan memiliki masalah heteroskedastisitas apabila nilai error 
atau residual model yang diamati tidak memiliki varian yang konstan dati satu observasi ke observasi yang lainnya. Hasil uji heteroskedastisitas berdasarkan uji White dapat dilihat pada tabel 5 berikut :

\section{Tabel 5 \\ Uji Heteroskedastisitas}

Heteroskedasticity Test: Breusch-Pagan-Godfrey

\begin{tabular}{lclc}
\hline \hline F-statistic & 1.019113 & Prob. F(3,7) & 0.4398 \\
Obs*R-squared & 3.343900 & Prob. Chi-Square(3) & 0.3416 \\
Scaled explained SS & 1.704062 & Prob. Chi-Square(3) & 0.6360
\end{tabular}

Sumber : Data Evies (data diolah)

Berdasarkan tabel 4.3 di atas dapat kita lihat bahwa nilai probabilitas Obs*R-square sebesar 3.343 dibandingkan dengan tingkat signifikansi (alpha) sebesar 0.341. Jika nilai probabilitas signifikansinya di atas 0,05 maka bisa ditarik kesimpulan bahwa tidak terjadi heteroskedastisitas.

\subsection{Pengujian Hipotesis}

\subsubsection{Secara Parsial (Uji t)}

Berdasarkan hasil pengolahan data dapat dilihat nilai uji-t sebagai berikut:

\begin{tabular}{crrr}
\multicolumn{4}{c}{ Tabel 6 } \\
Uji-t & \\
Variable & Coefficient & Std. Error & t-Statistic \\
\hline C & 11960.61 & 71627.19 & 0.166984 \\
LOG(X1) & 5228.998 & 1274.245 & 4.103606 \\
LOG(X2) & -16452.24 & 15645.73 & -1.051548 \\
X3 & -111.4461 & 119.6290 & -0.931598
\end{tabular}

\section{Pengaruh Jumlah Usia Produktif \\ Terhadap Pertumbuhan Ekonomi}

Dari hasil perhitungan uji secara parsial didapatkan nilai $\mathrm{t}$ hitung sebesar 4.103606 dengan signifikansi 0.0046, serta $\mathrm{t}$ tabel sebesar 1.943. Karena nilai signifikansi lebih kecil daripada 0,05 dan nilai $\mathrm{t}$ hitung lebih besar dari pada $\mathrm{t}$ tabel maka dapat disimpulkan bahwa jumlah usia produktif berpengaruh positif signifikan terhadap pertumbuhan ekonomi di Kabupaten Bireuen, sehingga hipotesis yang diajukan diterima kebenarannya.

\section{Pengaruh Kemiskinan Terhadap Pertumbuhan Ekonomi}

Dari hasil perhitungan uji secara parsial didapatkan nilai $t$ hitung sebesar -1.051548 dengan signifikansi 0.3279 , serta $\mathrm{t}$ tabel sebesar 1.943 . Karena nilai signifikansi lebih besar daripada 0,05 dan nilai $\mathrm{t}$ hitung lebih kecil dari pada $\mathrm{t}$ tabel maka bisa ditarik kesimpulan bahwa kemiskinan tidak berpengaruh terhadap pertumbuhan ekonomi di Kabupaten Bireuen, sehingga hipotesis yang diajukan ditolak kebenarannya.

\section{Pengaruh Inflasi Terhadap Pertumbuhan Ekonomi}

Dari hasil perhitungan uji secara parsial diperoleh nilai $t$ hitung sebesar --0.931598 dengan signifikansi 0.3826 , serta $\mathrm{t}$ tabel sebesar 1.943 . Karena nilai signifikansi lebih besar daripada 0,05 dan nilai $\mathrm{t}$ hitung lebih kecil dari pada $\mathrm{t}$ tabel maka bisa ditarik kesimpulan bahwa inflasi tidak berpengaruh terhadap pertumbuhan ekonomi di Kabupaten Bireuen, sehingga hipotesis yang diajukan ditolak kebenarannya.

\subsubsection{Uji Serempak (Uji F)}

Berdasarkan hasil pengolahan data bisa dilihat nilai uji-F sebagai berikut:

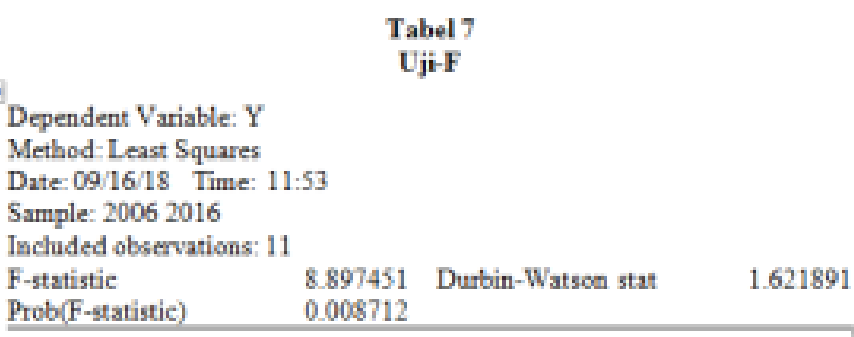

Berdasarkan Tabel 4.7 di atas bisa dilihat bahwa hasil uji $\mathrm{F}$ menunjukkan nilai $\mathrm{F}_{\text {hitung }}$ sebesar 8.897451 dengan signifikansi sebesar 0.008712 . Nilai signifikansi tersebut lebih kecil daripada 0.05 sehingga bisa ditarik kesimpulan bahwa variabel independen yaitu jumlah usia produktif, kemiskinan dan inflasi secara simultan berpengaruh signifikan terhadap pertumbuhan ekonomi Kabupaten Bireuen sehingga hipotesis yang diajukan diterima.

\subsubsection{AnalisisDeterminasi $\left(R^{2}\right)$}

Pada model linear berganda ini, akan bisa dilihat besarnya kontribusi untuk variabel bebas secara serentak terhadap variabel terikatnya dengan melihat besarnya koefisien determinasi totalnya $\left(\mathrm{R}^{2}\right)$. Nilai $\mathrm{R}^{2}$ memiliki interval antara 0 sampai $1\left(0 \leq R^{2} \geq 1\right)$. Semakin besar $R^{2}($ mendekati 1), semakin baik hasil untuk model regresi tersebut dan semakin mendekati 0 , maka variabel independen secara menyeluruh tidak bisa 
menjelaskan variabel independen (Sulaiman, 2004).

Nilai AdjustR Square $\left(\mathrm{R}^{2}\right)$ pada tabel 4.5 sebesar 0.703197 atau $70,31 \%$. Artinya variabel independen yaitu jumlah usia produktif, kemiskinan dan inflasi dapat menerangkan variabel dependen yaitu pert sebesar 70,31\%, sedangkan sisanya sebesar $26,7 \%$ diterangkan oleh variabelvariabel lain yang tidak di masukkan dalam model regresi pada penelitian ini.

\subsubsection{Koefisien Korelasi $(\mathrm{R})$}

Menurut (Supranto, 2006) mengenai analisis korelasi ialah suatu cara untuk melihat kuat ataupun tidaknya hubungan antara variabel $\mathrm{x}$ dengan variabel y apabila bisa dinyatakan dengan fungsi linier atau paling tidak mendekati dan dihitung dengan sebuah nilai yang dikenal dengan koefisien korelasi.

\subsection{Pembahasan}

\subsubsection{Pengaruh Jumlah Penduduk Usia Produktif Terhadap Pertumbuhan Ekonomi}

Berdasarkan hasil penelitian diketahui bahwa jumlah penduduk usia produktif berpengaruh positif signifikan terhadap pertumbuhan ekonomi di Kabupaten Bireuen. Hal ini disebabkan semakin tinggi jumlah penduduk usia produktif atau yang masih mampu bekerja, akan meningkatkan produksi sebagai komponen dari PDRB yang menjadi acuan peningkatan pertumbuhan ekonomi suatu daerah. Penduduk dengan usia produktif bergerak di berbagai sektor, baik sektor menghasilkan barang, maupun sektor penjualan jasa.

\subsubsection{Pengaruh Kemiskinan Terhadap Pertumbuhan Ekonomi}

Berdasarkan hasil penelitian diketahui bahwa kemiskinan tidak berpengaruh terhadap pertumbuhan ekonomi di Kabupaten Bireuen. Hal ini disebabkan, tingkat kemiskinan di Kabupaten Bireuen bukanlah penduduk miskin dengan tingkat keparahan tertinggi, mereka hanya kekurangan penghasilan untuk memenuhi keperluan hidup yang lain seperti membangun rumah, sedangkan untuk memenuhi kebutuhan pangan mereka masih mampu.

\subsubsection{Pengaruh Inflasi \\ Terhadap \\ Pertumbuhan Ekonomi}

Berdasarkan hasil penelitian diketahui bahwa inflasi tidak berpengaruh terhadap pertumbuhan ekonomi di Kabupaten Bireuen. Hal ini disebabkan, tingkat inflasi di Kabupaten Bireuen tidaklah setinggi inflasi di Kota Banda Aceh, Sabang dan Lhokseumawe. Untuk kebutuhan pokok, masyarakat di Kabupaten Bireuen yang umumnya petani memiliki cadangan pangan dari hasil bertani padi dan sayursayuran.Inflasi tinggi di Kabupaten Bireuen hanya terjadi untuk barang tersier seperti elektronik dan pakaian. Ketika kondisi inflasi tersebut, masyarakat memilih untuk tidak membelanjakan uang mereka untuk kebutuhan pendukung, mengutamakan kebutuhan primer dan pendidikan anak-anak mereka.

\section{PENUTUP}

\subsection{Kesimpulan}

Berdasarkan hasil analisis data dan pembahasan maka bisa ditarik kesimpulannya sebagai berikut:

1. Jumlah usia produktif berpengaruh signifikan terhadap pertumbuhan ekonomi di Kabupaten Bireuen pada periode 20062016.

2. Kemiskinan tidak berpengaruh terhadap pertumbuhan ekonomi di Kabupaten Bireuen pada periode 2006-2016.

3. Inflasi tidak berpengaruh terhadap pertumbuhan ekonomi di Kabupaten Bireuen pada periode 2006-2016.

\subsection{Saran}

1. Pemerintah Kabupaten Bireuen perlu melakukan perluasan lapangan kerja mengingat jumlah usia produktif di Kabupaten Bireuen sangat tinggi, hal ini dikhawatirkan terjadi pengangguran besarbesaran yang dapat mempengaruhi stabilitas perekonomian di Kabupaten Bireuen.

2. Pemerintah Kabupaten perlu mencari strategi pengentasan kemiskinan dengan perluasan akses sumber daya kepada masyarakat, agar pertumbuhan ekonomi Bireuen semakin baik.

3. Pemerintah Kabupaten Bireuen perlu melakukan pengendalian harga-harga barang dengan cara melakukan operasi 
pasar dan pengentasan oknum yang melakukan permainan harga barang.

\section{KEPUSTAKAAN}

Latumaerissa (2011) Bank dan Lembaga Keuangan Lain. Jakarta: Salemba Empat.

Mahalli, K. (2005) 'Analisis Kebijakan Fiskal Kota Medan di Era Otonomi Daerah', Jurnal Perencanaan \& Pengembangan Wilayah, 1(1).

Mankiw, N. G., Quah, E. and Peter, W. (2012) Pengantar Ekonomi Mikro. Jakarta: Salemba Empat.

Miraza (2005) Perencanaan dan Pembangunan Wilayah. Bandung: ISEI.

Prasetyo, R. B. and Firdaus, M. (2009) 'Pengaruh Infrastruktur Pada Pertumbuhan Ekonomi Wilayah di Indonesia', Jurnal Ekonomi dan Kebijakan Pembangunan, 2(2), pp. 222236.

Subri, M. (2003) Ekonomi Sumber daya Manusia. Jakarta: PT. Raja Grafindo Persada.

Sugiyono (2009) Metode Penelitian Kuantitatif, Kualitatif dan $R \& D$. Bandung: Alfabeta.

Sukirno, S. (2002) Teori Mikro Ekonomi Cetakan Keempat Belas. Jakarta: Rajawali Pers.

Sukirno, S. (2005) Makroekonomi: Teori Pengantar. Jakarta: PT. Raja Grafindo Persada.

Sulaiman, W. (2004) Analisis Regresi Menggunakan SPSS. Yogyakarta: Andi.

Supranto (2006) Pengukuran Tingkat Kepuasan Pelanggan untuk Menaikkan Pangsa Pasar. Jakarta: Rineka Cipta.

Suryawati, C. (2004) 'Memahami Kemiskinan Secara Multidimensional', JMPK, 8(3), pp. 121-129.

Tambunan (2003) Perkembangan Sektor Pertanian di Indonesia: Beberapa Isu Penting. Jakarta: Ghalia Indonesia.

Todaro, M. P. (2006) Pembangunan Ekonomi di Dunia Ketiga. Jakarta: Erlangga. 